\title{
THE INFLUENCE OF JOB STRESS AND JOB CONFLICT ON JOB SATISFACTION
}

\author{
Mochamad Fickrie Alfian \\ Universitas Langlangbuana, Indonesia \\ alfianfickrie@gmail.com
}

\begin{abstract}
Some of the components of human resource management are job stress and job conflict. Job stress is important to pay attention to because it will have an impact on job satisfaction and job conflict to maintain relationships with colleagues. The purpose of this study was to determine the magnitude of the influence partially or simultaneously job stress and job conflict on job satisfaction in grabbike driver-partners in Bandung. The method used is descriptive analysis and verification. The data collection technique used is a literature study and distributing questionnaires with 88 respondents. The analytical method used is path analysis using SPSS 24.0 software. Based on the results of the research, the following findings were obtained: job stress on grabbike partners can be said to be quite good, besides that, job conflicts on grabbike partners are quite good and job satisfaction on grabbike partners is quite good. Partially job stress affects job satisfaction and job conflict affects job satisfaction. Also, simultaneously job stress and job conflict affect job satisfaction. These results suggest drivers not to cancel orders if they get orders, and drivers should improve their performance by not making picky orders so that they will get a greater chance of getting stable orders.
\end{abstract}

Keywords: Job Stress, Job Conflict, Job Satisfaction

\section{INTRODUCTION}

According to Marwansyah (2014), an increasingly complex and challenging environment that is transformed by factors such as globalization, technological developments, the increasingly rapid spread of new technologies, to the development and use of knowledge colors the landscape of the 21 st century. These factors have caused drastic changes and influenced various aspects of people's lives around the world, including Indonesia. Inevitably, changes in the complex and dynamic environment will affect the ability of organizations, especially business organizations, to compete and maintain their competitiveness. This capability, in turn, will be largely determined by the quality of human resources or human capital that is owned.

At the micro-level, the increased business competition will encourage companies to incorporate human resource issues into the company's development strategy. Companies not only need to have high productivity but also must demonstrate excellence in the ability to produce quality goods and services, as varied as customer tastes, accompanied by convenience and comfort as well as timeliness. The competitiveness of a company will be largely determined by the competence of its human resources. The ability of employees to take advantage of science and technology will be a very important source of competitive advantage.

Grab is an online transportation company operating in Indonesia. Grab was founded by Anthony Tan and Hooi Ling Tsn who are Malaysian citizens, Grab (previously known as GrabTaxi) is one of the $\mathrm{O} 2 \mathrm{O}$ platforms headquartered in Singapore and the most frequently used in Southeast Asia, providing services for necessities daily activities for customers including travel, food delivery, delivery of goods and payments using digital wallets. Grab currently provides services in Singapore, Indonesia, the Philippines, Malaysia, Thailand, Vietnam, Myanmar, and Cambodia. Grab believes that every community in Southeast Asia should 
benefit from the digital economy, and the company provides access to safe and affordable transportation services, food delivery and delivery services, as well as mobile and financial payment services. Grab is also the first "decacorn" (a term for a startup that has a company valuation of US $\$ 10$ billion or 10 times the first "unicorn") in Southeast Asia.

In Indonesia, Grab serves ordering vehicles such as ojek (GrabBike), cars (GrabCar), and taxis (GrabTaxi) as well as couriers (GrabExpress), food delivery (GrabFood), and social carpooling (GrabHitch Car). Currently Grab is available in 125 cities throughout Indonesia, from Aceh to Papua.

The phenomenon of the number of Grab drivers moving to Gojek as reported by (makassar.tribunnews.com, 26 June 2019). The transfer occurred as a result of the Karya Anak Bangsa company having more benefits than its competitors. One of the Grab Drivers said this was also related to the problems of those who felt difficulties with the payment system from the applicator. Drivers are more interested in the Gojek payment system than competitors. The bonus payments provided by Gojek can be cashed directly on the same day, while payments from Grab can only be disbursed the following day. Also, Gojek is considered to have more respect for drivers as evidenced by the case of drivers suddenly fainting while driving consumers, then the Gojek task force immediately responded quickly so that the victim's life was saved.

This phenomenon shows that there is dissatisfaction in working as a Grab Driver. The driver's dissatisfaction occurs because of job stress and job conflicts. Stress can be defined as a situation in which an employee feels psychologically depressed in dealing with workload and the environment in which he works (Ganyang, 2018). According to Hasibuan (2014), the factors that cause stress for employees are as follows: (1) Difficult and excessive workload; (2) Pressure and attitude from leadership that is not fair and reasonable; (3) Inadequate job time and equipment; (4) Interpersonal conflicts with leaders or job groups; (5) Remuneration is too low; (6) Family problems such as children, wives, parents-in-law, and others.

In human relations there are differences of opinion, goals, needs, desires, habits, values, differences in perceptions, and so on. Even among employees in the organization, some differences can lead to conflicts. In the life of an organization, conflict is inevitable. The characteristics of a mature group are the desire and ability to raise various conflicts to the surface as early as possible so that they can be discussed and resolved so that they do not develop into the direction of the organizational split. Conflict is less likely to be eliminated, but its negative effects can be reduced by bringing it to the surface and discussing it (Rachman, 2016).

Job satisfaction is one of the most important factors to get optimal job results. When a person feels satisfaction at work, he will do everything possible to the best of his ability to complete his job assignments. Thus, productivity and job results will increase optimally. However, in reality, in Indonesia and several other countries, overall job satisfaction has not yet reached the maximum level (Badriyah, 2015).

To deepen the problem of job stress variables and job conflict on job satisfaction, a pre-survey was conducted on 20 respondents. The presurvey results show that job stress, job conflict, and job satisfaction on Grabbike drivers are still problematic. So, this research aimed to determine the magnitude of the influence partially or simultaneously job stress and job conflict on job satisfaction in grabbike driver-partners in Bandung.

\section{METHODS}

In this study, the primary data source was obtained from the results of 
a questionnaire distributed to several Grabbike drivers in the city of Bandung. Secondary data in this study were obtained from books, previous research, and the internet. Data collection was carried out by observation, interviews, literature study, and questionnaires. The population in this study were Grabbike driver-partners in the city of Bandung, especially in the Gegerkalong, Lembang, and surrounding areas. The sample in this study was 88 respondents of Grabbike driver PT. Grab Indonesia in Bandung City.

Criteria for determining respondents as follows: (1) Inclusion criteria: (a) Grabbike driver-partners in the Gegerkalong area, Lembang dsk, (b) Grabbike driver-partners who have worked for $\geq 6$ months, (c) Willing to be involved in research; (2) Exclusion Criteria: (a) Go-Ride driver-partners who are not in the Gegerkalong area, Lembang dsk, (b) Go-Ride driverpartners who job $<6$ months, (c) Not willing to be involved in the research.

This research uses descriptive analysis and verificative. In the verificative analysis using path analysis and hypothesis testing. The hypotheses in this study are as follows: (1) Job stress on Grabbike driver-partners is quite potential; (2) job conflicts with Grabbike driver-partners are quite potential; (3) Job satisfaction with Grabbike driver-partners is not optimal; (4) There is an effect of job stress on job satisfaction on Grabbike driver partners; (5) There is an effect of job conflict on job satisfaction on Grabbike driverpartners; (6) There is an effect of job stress and job conflict on job satisfaction on Grabbike driver-partners.

\section{RESULTS AND DISCUSSION}

Descriptive research is used to analyze data by describing or depicting late data collected as it is without intending to make general conclusions or generalizations. Descriptive analysis in this study regarding Stress, Conflict, and Job Satisfaction of Partners (Driver Grabbike) PT. Grab Indonesia.
To find an overview of each variable under study, a description will be carried out based on the percentage score of each respondent's answer. To provide an interpretation of the percentage of scores that have been obtained, categorization is carried out as as in the following table:

Table 1. Categorization Guidelines

\begin{tabular}{ccc}
\hline $\begin{array}{c}\text { Interval } \\
\text { width }\end{array}$ & $\begin{array}{c}\text { Score } \\
\text { percentage }\end{array}$ & Information \\
\hline $1,00-1,79$ & $20,0 \%-35,9 \%$ & Not very good \\
$1,80-2,59$ & $36,0 \%-51,9 \%$ & Not good \\
$2,60-3,39$ & $52,0 \%-67,9 \%$ & Fairly Good \\
$3,40-4,19$ & $68,0 \%-83,9 \%$ & Good \\
$4,20-500$ & $84,0 \%-100,0 \%$ & Very good \\
\hline \multicolumn{3}{c}{ Source: Processed data (2020) }
\end{tabular}

To find out how job stress is on grabbike driver-partners, PT. Grab Indonesia, then analyzed the data from the results of the distribution of questionnaires that have been distributed to 88 respondents, while the statements contained in the questionnaire consisted of 9 statements regarding job stress as the independent variable $\mathrm{X} 1$. Below is a recapitulation of the results of a questionnaire regarding job stress which is presented in tabular form, including:

Table 2. Recapitulation of Respondents' Responses Regarding job Stress

\begin{tabular}{|c|c|c|c|}
\hline Statemer & Score & Average & Category \\
\hline P1 & 268 & 3,04 & Fairly Good \\
\hline P2 & 269 & 3,05 & Fairly Good \\
\hline P3 & 276 & 3,13 & Fairly Good \\
\hline P4 & 267 & 3,03 & Fairly Good \\
\hline P5 & 253 & 2,87 & Fairly Good \\
\hline P6 & 362 & 4,11 & Good \\
\hline P7 & 285 & 3,23 & Fairly Good \\
\hline P8 & 329 & 3,73 & Good \\
\hline P9 & 285 & 3,23 & Fairly Good \\
\hline Total & 2594 & 3,26 & Fairly Good \\
\hline
\end{tabular}

Based on Table 2 which has been described, describes the responses of respondents to 9 statements regarding 
the variable job stress (X1) as a whole. Based on the results of the processing presented, it can be seen that the total score for the job stress variable $(\mathrm{X} 1)$ is 2594 out of 9 statements of 88 respondents who answered so that the average score was obtained referring to the assessment criteria in the fairly good category. If it is drawn with a continuum line according to these criteria it will look like this: $=3960$

Maximum index value $=5 \times 9 \times 88$

Minimum index value $=1 \times 9 \times 88$ $=792$

Interval distance $=$ (maximum value-minimum value):5=(3960 - 792): 5 $=633.6$
Percentage score $=$ (total score: maximum score $) \times 100 \%=(2594: 3960)$ $x 100 \%=65.5 \%$

From this range, categorization guidelines are obtained as in the following table:

Table 3. Stress Variable Actual Score Category

\begin{tabular}{cc}
\hline Interval Width & Information \\
\hline $792-1425,5$ & Not very good \\
$1425,6-2059,1$ & Not good \\
$2059,2-2692,7$ & Fairly Good \\
$2692,8-3326,3$ & Good \\
$3326,4-3960$ & Very good \\
\hline
\end{tabular}

Source: Processed data (2020)

$\begin{array}{llllll}20 \% & 36 \% & 52 \% & 68 \% & 84 \% & 100 \%\end{array}$

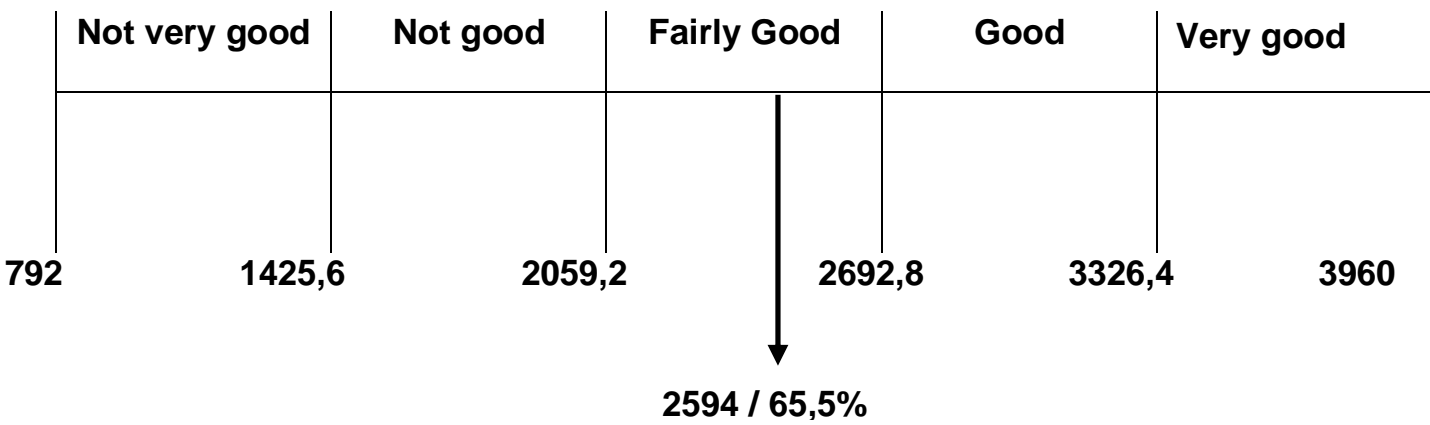

Figure 1. Job Stress Continuum Line

Source: Processed data (2020)

Based on the continuum line in Figure 1, it can be explained that the responses of respondents regarding Job Stress at Partners (Drivers) PT. Overall, Grab Indonesia is in a fairly good category with a percentage of $65,5 \%$. Thus, based on these results as well as answering research hypothesis number 1 regarding Job Stress at Partners (Driver) PT. Grab Indonesia is good enough, so the hypothesis is accepted.

To find out how job conflicts with grabbike driver-partners, PT. Grab Indonesia, then a questionnaire was distributed consisting of 9 statements regarding job conflict as an independent variable $\mathrm{X} 2$. Below is a recapitulation of the results of a questionnaire regarding job conflict which is presented in tabular form, including:

\section{Table 4. Recapitulation of Respondents Responses Regarding Job Conflicts}

\begin{tabular}{cccc}
\hline Statement & Score & Average & Category \\
\hline P10 & 279 & 3,17 & Fairly Good \\
P11 & 279 & 3,17 & Fairly Good \\
P12 & 289 & 3,28 & Fairly Good \\
P13 & 284 & 3,22 & Fairly Good \\
P14 & 285 & 3,23 & Fairly Good \\
P15 & 269 & 3,05 & Fairly Good \\
P16 & 267 & 3,03 & Fairly Good \\
P17 & 274 & 3,11 & Fairly Good \\
P18 & 263 & 2,98 & Fairly Good \\
Total & $\mathbf{2 4 8 9}$ & $\mathbf{3 , 1 3}$ & Fairly Good \\
\hline \multicolumn{4}{c}{ Source: Processed data (2020) } \\
\multicolumn{5}{c}{ Based on Table 4 it can be seen }
\end{tabular}

that the total score for the job conflict 
variable (X2) is 2489 out of 9 statements of 88 respondents who answered so that the average score was obtained referring to the assessment criteria in the fairly good category. If it is drawn with a continuum line according to these criteria it will look like:

Maximum index value $=5 \times 9 \times 88$ $=3960$

Minimum index value $=1 \times 9$

$$
\begin{aligned}
& \begin{array}{c}
x 8=792 \\
\text { Interval distance }=\text { (maximum }
\end{array} \\
& \text { value }- \text { minimum value }): 5 \\
& =(3960-792): 5 \\
& =633.6 \\
& \quad \text { Percentage score }=\text { (total score } \\
& : \text { maximum value }) \times 100 \% \\
& =(2489: 3960) \times 100 \% \\
& =62.8 \% \\
& \quad 68 \% \quad 84 \%
\end{aligned}
$$

$20 \%$

$36 \%$

$52 \%$

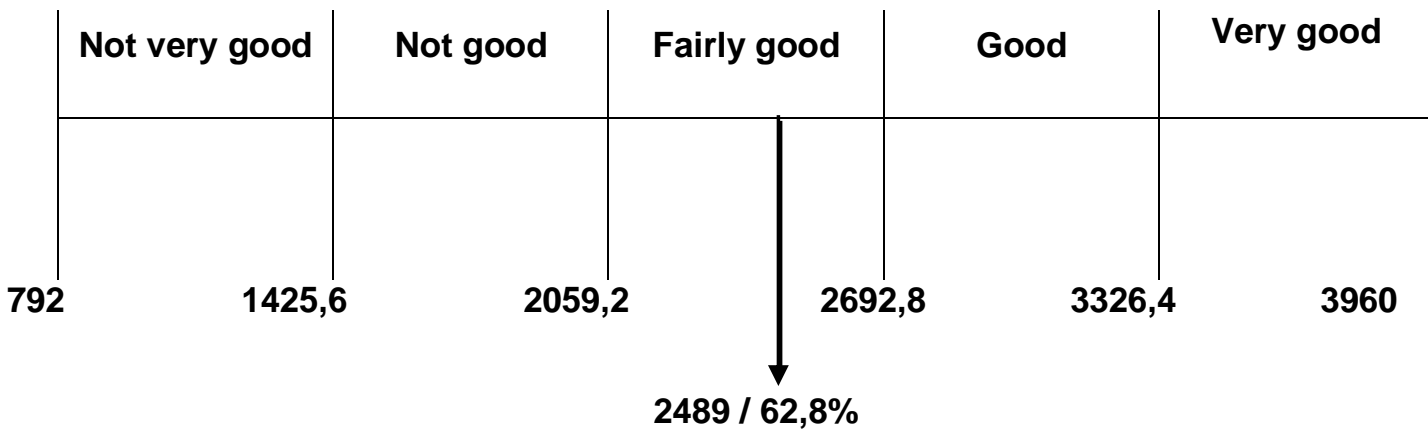

Figure 2. Job Conflict continuum line

Source: Processed data (2020)

Based on the continuum line in Figure 2, it can be explained that the responses of respondents regarding the Job Conflict of PT Grab Indonesia's Partners (Drivers) as a whole are in the fairly good category with a percentage of $62.8 \%$. Thus, based on these results as well as answering the research hypothesis No.2 regarding Job Conflict in Partners (Drivers) PT. Grab Indonesia is good enough, so the hypothesis is accepted.

To find out how job satisfaction is with grabbike driver-partners, PT. Grab Indonesia, then distributed a questionnaire consisting of 12 statements regarding job satisfaction as the independent variable $\mathrm{Y}$. Below is a recapitulation of the results of the questionnaire regarding job conflicts which are presented in tabular form, including:
Table 5. Recapitulation of Respondents' Responses Regarding Job Satisfaction

\begin{tabular}{cccc}
\hline Statement & Score & Average & Category \\
\hline P19 & 261 & 2,96 & Fairly Good \\
P20 & 284 & 3,22 & Fairly Good \\
P21 & 275 & 3,12 & Fairly Good \\
P22 & 277 & 3,14 & Fairly Good \\
P23 & 269 & 3,05 & Fairly Good \\
P24 & 273 & 3,10 & Fairly Good \\
P25 & 276 & 3,13 & Fairly Good \\
P26 & 289 & 3,28 & Fairly Good \\
P27 & 276 & 3,13 & Fairly Good \\
P28 & 281 & 3,19 & Fairly Good \\
P29 & 271 & 3,07 & Fairly Good \\
P30 & 283 & 3,21 & Fairly Good \\
Total & $\mathbf{3 3 1 5}$ & $\mathbf{3}, 13$ & Fairly Good \\
\hline \multicolumn{4}{c}{ Source: Processed data (2020) }
\end{tabular}

Based on Table 5, it can be seen that the total score for the Job Satisfaction variable $(Y)$ is 3315 out of 12 statements of 88 respondents who answered so that the average score refers to the assessment criteria in the fairly good category. If it is drawn with a 
continuum line according to these criteria it will look like this:

Maximum index value $=5 \times 12$ $x 88=5280$

Minimum index value $=1 \times 12 \times 88$ $=1056$

Interval distance $=$ (maximum value - minimum value): 5
$=(5280-1056): 5$

$=844.8$

Percentage score $=$ (total score: maximum score) $\times 100 \%$ $=(3315: 5280) \times 100 \%$ $=62.7 \%$

$20 \%$

$36 \%$

$52 \%$

$68 \%$

$84 \%$

$100 \%$

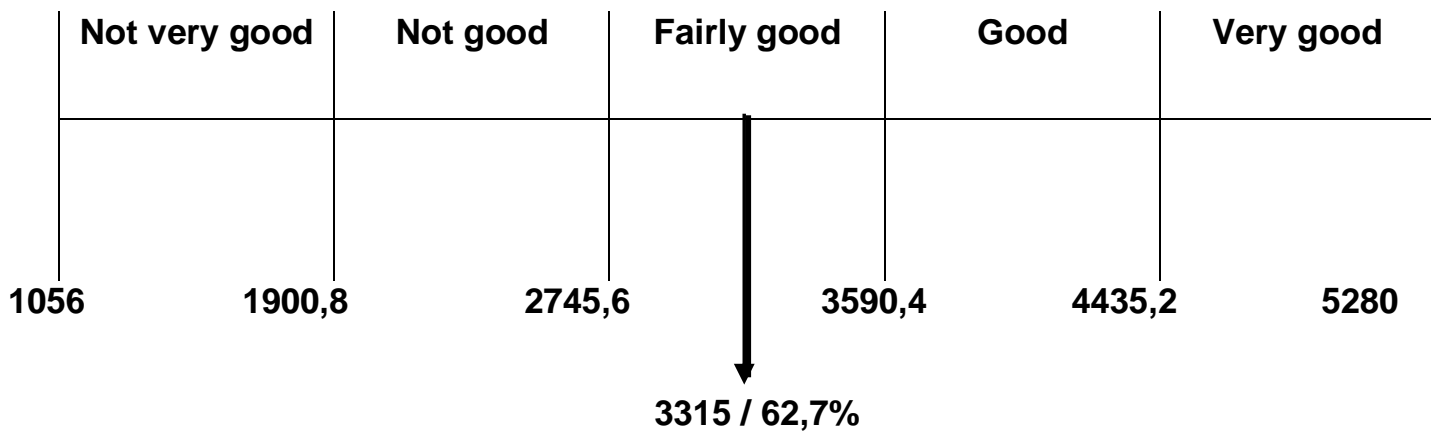

Figure 3. Job Satisfaction continuum line

Source: Processed data (2020)

Based on the continuum line in Figure 3 it can be explained that the responses of respondents regarding Job Satisfaction at Partners (Drivers) PT. Overall, Grab Indonesia is in a fairly good category with a percentage of $62.7 \%$. Thus, based on these results as well as answering research hypothesis number 3 regarding Job Satisfaction at Partners (Drivers) PT. Grab Indonesia is good enough, so the hypothesis is rejected.

In this section the research will be analyzed verificative, namely, in looking for the influence of Job Stress (X1) and Job Conflict $(\mathrm{X} 2)$ as independent variables and Job Satisfaction $(\mathrm{Y})$ as the dependent variable, this will be tested with statistics using the path analysis method.

Table 6. Pearson Correlation

\begin{tabular}{llrrr}
\hline \multicolumn{4}{c}{ Correlations } \\
total_x1 & total_x2 & total_y \\
\hline total_x1 & Pearson Correlation & 1 & $.621^{* *}$ & $.777^{* *}$ \\
& Sig. (2-tailed) & & .000 & .000 \\
& $\mathrm{~N}$ & 88 & 88 & 88 \\
total_x2 & Pearson Correlation & $.621^{* *}$ & 1 & $.727^{* *}$ \\
& Sig. (2-tailed) & .000 & & .000 \\
& $\mathrm{~N}$ & 88 & 88 & 88 \\
total_yy & Pearson Correlation & $.777^{* *}$ & $.727^{* *}$ & 1 \\
& Sig. (2-tailed) & .000 & .000 & \\
& $\mathrm{~N}$ & 88 & 88 & 88 \\
**. Correlation is significant at the 0.01 level (2-tailed). \\
\hline \multicolumn{4}{c}{ Source: Data processed (2020) }
\end{tabular}


In Table Pearson Correlation, it can be explained that: (1) The relationship between Job Stress and Job Conflict is 0.621 . The correlation value is positive, which is in the strong category, which indicates that there is a strong relationship between Job Stress and Job Conflict, where the better the Job Stress, the better the Job Conflict will be followed and vice versa; (2) The relationship between Job Stress and Job Satisfaction is 0.777 . The correlation value is positive which is in the strong category, which indicates that there is a relatively strong relationship between
Job Stress and Job Satisfaction where the better Job Stress, the better Job Satisfaction will be followed and vice versa; (3) The relationship between Job Conflict and Job Satisfaction is 0.727 . The correlation value is positive, which is in the very strong category, which indicates that there is a very strong relationship between Job Conflict and Job Satisfaction where the better the Job Conflict, the better Job Satisfaction will be followed and vice versa. then the hypothesis test is shown in the table below:

Table 7. Partial Hypothesis Test

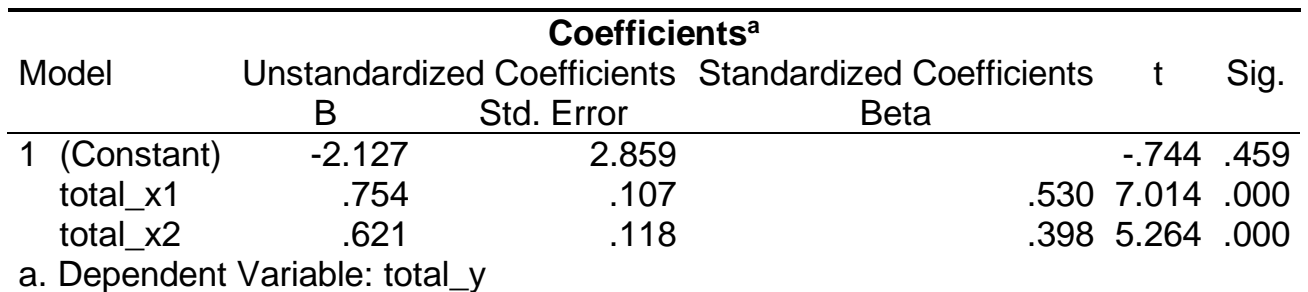

Source: Data processed (2020)

In the table 7 with the following conditions, a / $2=0.05 / 2=0.025$ and $\mathrm{dk}=(\mathrm{n}-\mathrm{k}-1)$ or $88-2-1=85$, which is 1.988. In the coefficient table, the $T$ count of Job Stress (X1) on Job Satisfaction $(Y)$ is 7,014 with a probability value $(\mathrm{sig})=0,000$, because the $t$ value is greater than t table 7,014> $1,988)$. Based on the hypothesis testing that has been done, it states that $T$ count is in the rejection area of $\mathrm{HO}$ or in other words that Job Stress partially affects Job Satisfaction of the partner (Driver) PT. Grab Indonesia. Based on these results, research hypothesis number 4 is suspected that Job Stress (X1) has a direct effect on accepted Job Satisfaction.

while for job satisfaction in the table, T count of Job Conflict (X2) on Job Satisfaction $(Y)$ is 5,264 with a probability value $(\mathrm{sig})=0,000$, because $T$ count is greater than $t$ table 5,264> $1,988)$. Based on the hypothesis testing that has been done, it is stated that $t$ count is in the rejection area of $\mathrm{HO}$ or other words, the Job Conflict partially affects the Job Satisfaction of PT. Grab Indonesia. Based on these results, research hypothesis number 5 is suspected that Job Conflict (X2) has a direct effect on accepted Job Satisfaction. 
Almana : Jurnal Manajemen dan Bisnis Vol. 4 No. 3/ December 2020

ISSN 2579-4892 print/ ISSN 2655-8327 online

Table 8. Simultaneous Hypothesis Test

\begin{tabular}{|c|c|c|c|c|}
\hline \multicolumn{5}{|c|}{ ANOVA $^{a}$} \\
\hline Model & Sum of Squares df & Mean Square & $\mathrm{F}$ & Sig. \\
\hline 1 Regression & $2237.514 \quad 2$ & 1118.757 & 99.896 & $.000^{\mathrm{b}}$ \\
\hline Residual & 951.92985 & 11.199 & & \\
\hline Total & 3189.44387 & & & \\
\hline \multicolumn{4}{|c|}{ a. Dependent Variable: total y } & \\
\hline \multicolumn{5}{|c|}{ b. Predictors: (Constant), total $x 2$, total $x 1$} \\
\hline
\end{tabular}

Source: Data processed (2020)

In the $\mathrm{F}$ distribution table with the following conditions $\alpha=0.05$ and the $\mathrm{dk}$ numerator $\mathrm{k}(2)$, and the denominator et $\mathrm{al}=(\mathrm{n}-\mathrm{k}-1)$ or $88-2-1=85$, which is 3.10 . In the table, the $F$ value is 99.896 with the probability value $(\mathrm{sig})=0.000$, because the $F$ value is calculated (99.896> 3.10). So, based on the hypothesis testing that has been done, it states that $F$ count is in the rejection area of $\mathrm{HO}$ or in other words that Job Stress and Job Conflict simultaneously affect Job Satisfaction in partners (Driver) of PT. Grab Indonesia. Based on these results, research hypothesis number 6 is suspected that Job Stress (X1) and Job Conflict (X2) have a simultaneous effect on Job Satisfaction (Y) at partner (Driver) PT. Grab Indonesia.

The results of the research on Job Stress on Job Satisfaction will have an impact on the level of satisfaction and dissatisfaction of partners with working as drivers. In this research, Job Stress makes a strong contribution. As stated by Siagian (2016), the symptoms of stress come from psychological, such as postponing tasks or work, this shows that the stress that arises is related to a person's dissatisfaction with his job. The results of this study are also in line with previous research conducted by Hanim (2016) which states that job stress affects job satisfaction.

In this research, job conflict makes a strong contribution. This is because there are many factors other than job conflicts that contribute to partner job satisfaction. The results of this study are also in line with previous research conducted by Putra (2019) which states that job conflict affects job satisfaction.

This section will explain the relationship and contribution between job stress and job conflict on job satisfaction. Based on the research results indicate that the partner (Driver) PT. Grab Indonesia between Job Stress and Job Conflict contributes to Job Satisfaction. Based on the research, there is a contribution between job stress and job conflict that better job stress will be followed by better job conflict. The results showed that job stress and job conflict contribute to and are accepted because job stress plays a role in being satisfied or dissatisfied with saturation, anxiety, anxiety, and a procrastinating job which is a manifestation of problems at a job (job dissatisfaction), job conflicts also play a role. because of the bad relationship between co-workers, strikes, is a form of dissatisfaction with his work.

In research the causes of job stress and job conflict contribute to job satisfaction, it is proven that there is a very strong contribution, this is indicated by job conflict contributes the most to job satisfaction, because job conflict is a manifestation of a different perception in seeing a situation, which Furthermore, it is applied in the form of actions that have created conflicts with certain parties (Fahmi, 2016). The results of this study are also in line with research conducted by Afrizal (2014), which suggests that 
there is a significant effect simultaneously (together) between the independent variables (Job Conflict and Job Stress) that affect the dependent variable (Job Satisfaction).

\section{CONCLUSION}

job stress on partners (Driver) PT. Grab Indonesia as a whole is quite good, but in some cases, there are shortcomings if the driver often cancels orders or is picky with orders, it will have an impact on the driver's account, such as the difficulty of getting orders in the future and even worse, they will get temporary suspension to permanent suspension. Meanwhile, Job Conflict on the partner (Driver) PT. Grab Indonesia as a whole is quite good, but there are still shortcomings such as recently the existence of a new system, namely a priority order system where if drivers are not picky, orders will continue to get orders continuously or stable every day and vice versa if drivers are lazy to choose -choosing orders will have difficulty getting orders, if like this it will continue to have an impact on the emergence of conflicts between other drivers who are waiting for orders in one area for example in a food restaurant.

Job Satisfaction with partners (Driver) PT. Grab Indonesia as a whole is quite good, but there are shortcomings for some drivers who find it difficult to get uneven orders, There is no career path or diamond scheme that will change in nominal at any time, and drivers are worried if they are suddenly suspended temporarily or permanently because of PT. Grab Indonesia is more concerned with consumers than the drivers themselves.

\section{REFERENCES}

Afrizal, Poundra Rizky. (2014). Pengaruh Konflik Kerja dan Stres Kerja terhadap Kepuasan Kerja
(Studi pada Karyawan PT. Taspen

Persero). Jurnal Administrasi

Bisnis. Retreived at

http://administrasibisnis.studentjo

urnal.ub.ac.id/index.php/jab/articl e/view/354

Badriyah, Mila. (2015). Manajemen Sumber Daya Manusia. Bandung: Pustaka Setia.

Fahmi, Irham. (2016). Manajemen Sumber Daya Manusia Teori dan Aplikasi. Bandung: Alphabeta.

Ganyang, Machmed Tun. (2018). Manajemen Sumber Daya Manusia Konsep dan Realita. Bogor: In Media.

Hanim, Mas Latifah. (2016). Pengaruh Stres Kerja Terhadap Kepuasan Kerja Serta Dampaknya Pada Kinerja Karyawan Hull Construction Di Pt. Dok Dan Perkapalan Surabaya. Jurnal IImu Manajemen. Retreived at https://jurnalmahasiswa.unesa.ac. id/index.php/jim/article/view/1721 2

Hasibuan, Malayu S.P. 2014. Human Resource Management. Jakarta: PT Bumi Aksara.

Marwansyah. (2014). Manajemen Sumber Daya Manusia. Bandung: Alphabeta

Putra, Yaserli Syah. dan Mayliza, Riri. (2019). Pengaruh Konflik dan Kejenuhan Terhadap Kepuasan Kerja Karyawan PT. PLN (Persero) Sektor Pembangkitan dan Pengendalian Pembangkitan Ombilin. Jurnal OSF Preprints. Retreived at https://osf.io/preprints/26cfd/

Rachman, Taufiq. (2016). Manajemen Sumber Daya Manusia Perusahaan. Bogor: Ghalia Indonesia.

Siagian, Sondang P. (2014). Manajemen Sumber Daya Manusia. Jakarta: PT Bumi Aksara. 